\title{
POLSKI RYNEK OBLIGACJI NIESKARBOWYCH - NOWE ZASADY REJESTRACJI OBLIGACJI ORAZ ANALIZA REJESTRU ZOBOWIĄZAŃ EMITENTÓW
}

\author{
Czesław Bartłomiej Martysz, dr \\ Instytut Finansów, Szkoła Główna Handlowa w Warszawie \\ iD https://orcid.org/0000-0003-2461-0121
}

\section{Streszczenie}

Po aferze Getback SA, w celu wzmocnienia nadzoru nad rynkiem obligacji, stworzono specjalny Rejestr Zobowiązań Emitentów (RZE), który ułatwia inwestorom wyszukiwanie informacji na temat papierów dłużnych. Rejestr ten po raz pierwszy ujawnił rzeczywisty rozmiar oraz kilka ważnych cech polskiego rynku obligacji nieskarbowych. Pierwszym celem artykułu jest pokazanie istotnych zmian prawa dotyczących rejestracji obligacji oraz ich potencjalnego wpływu na dalszy rozwój rynku. Drugim celem jest ukazanie nieznanej dotąd skali i głównych cechy rynku obligacji, w tym w szczególności obligacji komunalnych.

Pierwsza hipoteza brzmi: obowiązkowa rejestracja obligacji w KDPW wraz z publicznie dostępnym Rejestrem Zobowiązań Emitentów poprawiły przejrzystość i poziom bezpieczeństwa polskiego rynku obligacji nieskarbowych oraz ułatwiły obrót tymi papierami na rynku wtórnym. Druga hipoteza brzmi: Rejestr Zobowiązań Emitentów jest pierwszym publicznie dostępnym narzędziem do kompleksowej analizy polskiego rynku obligacji nieskarbowych, który ujawnił m.in. duże rozdrobnienie emitentów (w szczególności w obligacjach samorządowych), dominację emitentów kontrolowanych przez Skarb Państwa, przewagę obligacji o zmiennym oprocentowaniu oraz znaczącą liczbę obligacji zarejestrowanych poza KDPW.

Słowa kluczowe: obligacje, obligacje komunalne, obligacje nieskarbowe, rejestr obligacji, rejestr zobowiązań emitentów.

JEL Class: G10, G18, 016. 


\section{WSTĘP}

Skutkiem afer finansowych jest spadek zaufania inwestorów do rynku finansowego. Remedium na dostrzeżone po czasie patologie stają się przeważnie nowe przepisy i obostrzenia wzmacniające nadzór nad rynkiem finansowym. Przykładem jest afera spółki Getback SA, której obligacje w nieuczciwy sposób masowo oferowano osobom fizycznym. Jednym ze skutków tej afery była gruntowna przebudowa polskiego prawa w zakresie obligacji, w tym wprowadzenie obowiązku rejestracji obligacji w Krajowym Depozycie Papierów Wartościowych (KDPW). W ramach wzmocnienia nadzoru nad rynkiem obligacji stworzono specjalny Rejestr Zobowiązań Emitentów (RZE), który ułatwia inwestorom wyszukiwanie informacji na temat papierów dłużnych.

Pierwszym celem artykułu jest pokazanie istotnych zmian prawa dotyczących formy rejestracji obligacji oraz ich potencjalnego wpływu na dalszy rozwój rynku. Drugim celem jest ukazanie nieznanej dotąd skali i głównych cech polskiego rynku obligacji nieskarbowych.

Pierwsza hipoteza brzmi: obowiązkowa rejestracja obligacji w KDPW i publicznie dostępny Rejestr Zobowiązań Emitentów poprawiły przejrzystość i bezpieczeństwo rynku obligacji nieskarbowych ułatwiając obrót na rynku wtórnym. Druga hipoteza brzmi: Rejestr Zobowiązań Emitentów jest pierwszym publicznie dostępnym narzędziem do kompleksowej analizy polskiego rynku obligacji nieskarbowych, który ujawnił m.in. duże rozdrobnienie emitentów (w szczególności w obligacjach samorządowych), dominację emitentów kontrolowanych przez Skarb Państwa, przewagę obligacji o zmiennym oprocentowaniu oraz znaczącą liczbę obligacji zarejestrowanych poza KDPW.

W artykule zastosowano głównie dwie metody badawcze, tj. badanie literatury i aktów prawnych oraz badanie statystyczne w oparciu o dane z RZE na dzień 30 kwietnia $2020 \mathrm{r}$.

\section{REFORMA RYNKU OBLIGACJI NIESKARBOWYCH}

W dniu 2 maja 2018 r. spółka Getback SA złożyła wniosek o otwarcie postępowania restrukturyzacyjnego [Getback 2018]. Był to jeden z największych w Polsce emitentów obligacji, mających zarówno formę zdematerializowaną (tj. zapisu elektronicznego), jak i dokumentową ${ }^{1}$ (tj. formę materialną). Zgodnie $\mathrm{z}$ pierwotnym brzmieniem art. 8 ustawy o obligacjach, obligacje w formie zdematerializowanej mogły być zapisane w ewidencji prowadzonej m.in. przez firmy inwestycyjne i banki [Dz.U. 2015, poz. 238].

${ }^{1}$ Informacje o emisjach obligacji w formie dokumentowej można znaleźć m.in. w raportach EBI Getback SA, np. w raporcie EBI 39/2017 z 7 kwietnia 2017 r. 
Przyczyną, dla której spółka Getback SA emitowała obligacje w formie materialnej ${ }^{2}$, mogły być niższe koszty emisji z uwagi na brak pośrednictwa podmiotu prowadzącego ewidencję obligacji. Dawało to również spółce potencjalną możliwość dodatkowego wynagradzania osób oferujących jej obligacje.

Obligacje materialne w swej naturze nie były niczym złym - dzięki uproszczonej formie wykorzystywano je chociażby do emisji w ramach grup kapitałowych (tzw. intercompany), gdzie zarówno emitentami, jak i obligatariuszami były spółki z tej samej grupy kapitałowej ${ }^{3}$. Celem tego zabiegu była optymalizacja podatku PCC ${ }^{4}$. Obligacje typu intercompany pod kątem wartości nominalnej stanowiły ok. 23\% wszystkich obligacji przedsiębiorstw [Fitch Polska 2020].

Przed reformą, obligacje zdematerializowane (w formie zapisu elektronicznego) mogły być zarejestrowane zarówno w ewidencjach banków i domów maklerskich, jak i w Krajowym Depozycie Papierów Wartościowych (KDPW). Tylko rejestracja obligacji w KDPW dawała możliwość wprowadzenia obligacji do obrotu giełdowego. Obrót obligacjami nie mającymi formy dokumentu, ale zapisanymi w ewidencjach (poza KDPW), był możliwy tylko na rynku OTC ${ }^{5}$. Handel nimi był technicznie utrudniony, ponieważ obie strony transakcji musiały mieć założone rachunki powiernicze (ew. subdepozytowe ${ }^{6}$ ) w tej samej instytucji, która te papiery przechowywała w swej ewidencji. Rejestracja obligacji w centralnym depozycie KDPW upraszcza zatem operacyjnie obrót wtórny obligacjami. Historyczne i obecne formy rejestracji obligacji pokazano na rysunku 1.

Afera Getback jest przykładem missellingu ${ }^{7}$, gdzie główną rolę odegrały obligacje. Dla wielu obligatariuszy Getback SA był to pierwszy kontakt

${ }^{2}$ Warto podkreślić istotnie wyższe ryzyko posiadania obligacji materialnych (np. ryzyko utracenia lub uszkodzenia dokumentu) w stosunku do obligacji zdematerializowanych, które mogły być zapisywane tylko w rejestrach podmiotów profesjonalnych lub w KDPW.

${ }^{3}$ Przykładem obligacji intercompany zapisanych w ewidencjach firm inwestycyjnych i banków są obligacje PGE Górnictwo I Energetyka Konwencjonalna SA oraz ENEA Wytwarzanie Spółka z o.o., widoczne w tabeli 2.

${ }^{4}$ Zgodnie z art. 7 ust. 1 pkt 3 ustawy z dnia 9 września 2000 r. o podatku od czynności cywilnoprawnych [Dz.U. 2020, poz. 815 z późn zm.] stawka podatku od umowy pożyczki wynosi (od 01.2019 r.) $0,5 \%$ (wcześniej 2\%).

${ }^{5}$ Jest to rynek, gdzie transakcje są zawierane bezpośrednio pomiędzy stronami, tj. bez pośrednictwa giełdy.

${ }^{6}$ Rachunek subdepozytowy służy do ewidencji papierów wartościowych i jest prowadzony na rzecz funduszu inwestycyjnego przez subdepozytariusza. Subdepozytariuszem jest podmiot, któremu przekazano wykonywanie czynności z zakresu przechowywania aktywów funduszu.

${ }^{7}$ Misselling to proponowanie konsumentom nabycia usług finansowych, które nie odpowiadają potrzebom tych konsumentów ustalonym z uwzględnieniem dostępnych przedsiębiorcy informacji w zakresie cech tych konsumentów lub proponowanie nabycia usług finansowych w sposób nieadekwatny do charakteru tych usług; [NIK 2019]. 
obligacjami w ogóle, a część inwestorów błędnie utożsamiało bezpieczeństwo tych obligacji (jako instrumentu) z depozytami bankowymi [KNF 2018] ${ }^{8}$.

Afera Getback SA, pomijając kwestie missellingu obligacji czy oszustw księgowych, wywołała także dyskusję na temat konieczności stworzenia wspólnej bazy informacji o papierach dłużnych. Baza taka pozwalałaby weryfikować zadłużenie emitentów, a zwłaszcza to, czy nie rośnie ono w zbyt szybkim tempie. Warto podkreślić, że ani obligatariusze Getback SA ani KNF nie mieli pełnych bieżących informacji o liczbie i zakresie emisji prywatnych ${ }^{9}$ papierów wartościowych. Ponadto, z uwagi na brak regulacji, KNF nie była informowana ani o ofertach prywatnych obligacji ani o ich przydziałach [NIK 2019].

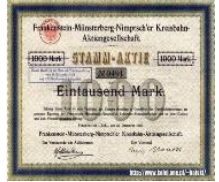

forma materialna
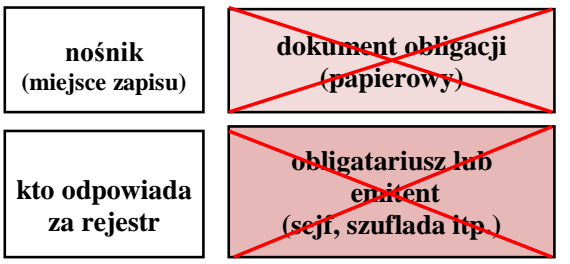

niemożliwy obrót publiczny (papiery niepubliczne)

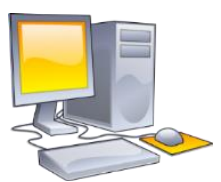

forma elektroniczna (zdematerializowane)
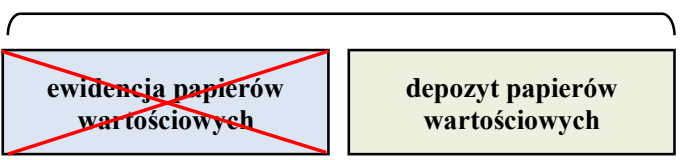
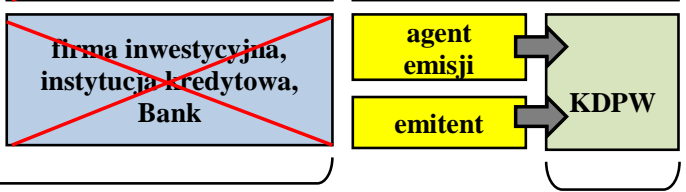

możliwy obrót publiczny

Rysunek 1. Formy rejestracji obligacji nieskarbowych po 1 lipca 2019 r.

Źródło: opracowanie własne.

${ }^{8} \mathrm{~W}$ związku ze skargami nabywców obligacji Getback SA w sprawie missellingu i wprowadzania ich w błąd, Komisja Nadzoru Finansowego (KNF) w dniu 29 maja 2018 r. zamieściła komunikat dotyczący oferowania przez banki obligacji korporacyjnych klientom posiadającym środki o wartości nie wyższej niż podlegające ochronie z tytułu gwarantowania depozytów, które w przekonaniu klientów objęte są systemem gwarantowania.

${ }^{9}$ Emisjami prywatnymi nazywano emisje kierowane do maksymalnie 149 inwestorów. Wśród 387 serii obligacji Getback SA aż 262 serie wyemitowano w ramach emisji prywatnych [NIK 2019]. Zgodnie ze stanowiskiem KNF z 12 sierpnia 2019 r. obecnie ofertę prywatną stanowi oferowanie obligacji do 1 podmiotu [KNF 2019]. 
Po ujawnieniu problemów Getback SA z regulowaniem zobowiązań wobec obligatariuszy rozpoczęto dyskusję nad zwiększeniem zakresu ochrony inwestorów aktywnych na rynku obligacji korporacyjnych, polegającej m.in. na zniesieniu materialnej formy obligacji. Efektem końcowym prac, w których kluczowy udział miał powołany przez Ministra Finansów Zespół Roboczy Rady Rozwoju Rynku Finansowego ds. przeglądu regulacji rynku obligacji korporacyjnych, była tzw. ustawa o wzmocnieniu nadzoru [Dz.U. 2018, poz. 2243 z późn. zm.]. Ustawa ta z dniem 1 lipca 2019 r. wprowadzała m.in. obowiązki:

- rejestracji wszystkich obligacji w KDPW (znosząc formę materialną) - bezpośrednio w KDPW w trybie $\mathrm{DvP}^{10}$ albo za pośrednictwem agenta emisji, którego rolą jest m.in. weryfikacja spełniania przez emitenta wymogów prawnych dotyczących emisji oraz zgodności dokumentacji i oświadczeń przedstawionych przez emitenta z wymogami dotyczącymi oferowania ${ }^{11}$,

- przekazania do KDPW do 31 marca 2020 r. informacji o obligacjach wyemitowanych przed 1 lipca 2019 r. wg stanu na dzień 31 grudnia 2019 r. ${ }^{12}$,

- comiesięcznej aktualizacji informacji o zobowiązaniach z obligacji ${ }^{13}$.

W celu zwiększenia przejrzystości rynku stworzono więc Rejestr Zobowiązań Emitentów przy KDPW [RZE, dostęp 4.06.2020], który obejmuje niemal wszystkie $^{14}$ nieskarbowe papiery dłużne, takie jak obligacje materialne, obligacje zdematerializowane i listy zastawne oraz częściowo certyfikaty inwestycyjne [Dz.U. 2020, poz. 89 z późn. zm., art. 48 ust 5e]. W RZE od 1 kwietnia 2020 r. ${ }^{15}$ można już m.in. sprawdzić:

${ }^{10}$ Delivery versus payment; chodzi o jednoczesną emisję i rejestrację obligacji w KDPW na podstawie $\S 5$ Szczegółowych Zasad Działania KDPW, pod warunkiem wcześniejszego wprowadzenia obligacji do ASO albo ich dopuszczenia do obrotu na rynku regulowanym [SZD KDPW].

${ }^{11} \mathrm{Wg}$ stanu prawnego na dzień 14 czerwca 2020 r. obligacje, w odniesieniu do których emitent nie zamierza ubiegać się o dopuszczenie do obrotu na rynku regulowanym ani o wprowadzenie do ASO, muszą być zarejestrowane w KDPW za pośrednictwem agenta emisji, zgodnie z art. 7a ustawy o obrocie [Dz.U. 2020, poz. 89 z późn. zm.].

${ }^{12}$ Informację o obligacjach (według stanu na 31.12.2019 r.) przekazuje do KDPW ich emitent (w przypadku obligacji materialnych) albo podmiot prowadzący ich ewidencję (w przypadku obligacji zapisanych w ewidencji) [Dz.U. 2018, poz. 2243 z późn. zm., art. 44].

${ }^{13}$ Aby uniknąć tego obowiązku należy zarejestrować papiery w KDPW, jednak wówczas pojawia się wynikający z par. 79 [Regulaminu KDPW] obowiązek informowania KDPW o każdym terminie wypłaty świadczeń z obligacji, a także, zgodnie z par. 80b [Regulaminu KDPW], informować o realizacji tych świadczeń, o ile nastąpiły z pominięciem systemów KDPW.

${ }^{14}$ Do nieskarbowych papierów dłużnych zalicza się również bankowe papiery wartościowe, zwane potocznie certyfikatami depozytowymi, emitowanymi przez banki na podstawie art. 90 ustawy z dnia 29 sierpnia 1997 r. Prawo bankowe [Dz.U. 2019, poz. 2357 z późn. zm.]. Papiery te mogą być nadal rejestrowane w ewidencji (tj. poza KDPW).

${ }_{15}$ Wprawdzie rejestr RZE uruchomiono już 1 lipca 2019 r., ale informacje o papierach wyemitowanych przed 1 lipca 2019 r. znalazły się w nim dopiero po 31 marca $2020 \mathrm{r}$. 
- łączną wartość nominalną obligacji wszystkich emitentów,

- wartość poszcz. serii obligacji wraz z rokiem emisji, datą spłat odsetek i kapitału (kalendarz płatności) oraz wysokością niewykonanych świadczeń,

- miejsce rejestracji obligacji (KDPW albo poza KDPW).

\section{KLUCZOWE CECHY RYNKU OBLIGACJI NIESKARBOWYCH WYNIKAJĄCE Z REJESTRU ZOBOWIĄZAŃ EMITENTÓW}

Poniższe analizy przeprowadzono w oparciu o plik XML ze strony Rejestru Zobowiązań Emitentów. W tabeli 1 ujęto najważniejsze statystyki polskiego rynku obligacji w ujęciu wartościowym. Łączna wartość nominalna wszystkich niezapadłych obligacji na dzień 30 kwietnia 2020 r. to ponad 203,5 mld PLN, z czego $53,4 \%$ zarejestrowano w KDPW. Wśród obligacji poza KDPW ${ }^{16}$ wartościowo dominują (76,6\%) obligacje emitentów innych niż banki i samorządy - gł. przedsiębiorstw ${ }^{17}$. Wartości nominalne w tabelach to łączne wartości nominalne obligacji danej kategorii, z tym, że wartości w walutach obcych przeliczono po następujących kursach: 4,5 EUR/PLN, 4,15 USD/PLN i 4,3 CHF/PLN.

Tabela 1. Emitenci obligacji wg typu podmiotu oraz miejsca rejestracji - ujęcie wartościowe na dzień 30.04.2020 (obligacje zapadające po 30.04.2020)

\begin{tabular}{|c|c|c|c|c|c|c|c|c|}
\hline \multicolumn{3}{|c|}{ Ogółem } & \multicolumn{3}{|c|}{ w tym w KDPW } & \multicolumn{3}{|c|}{ w tym poza KDPW } \\
\hline \multirow{2}{*}{$\begin{array}{c}\text { Typ } \\
\text { emitenta }\end{array}$} & \multirow{2}{*}{$\begin{array}{c}\text { Wartość } \\
\text { nom. w tys. } \\
\text { PLN }\end{array}$} & \multirow[b]{2}{*}{$\%$} & \multirow{2}{*}{$\begin{array}{c}\text { Wartość } \\
\text { nom. w tys. } \\
\text { PLN }\end{array}$} & \multicolumn{2}{|c|}{$\%$} & \multirow{2}{*}{$\begin{array}{c}\text { Wartość } \\
\text { nom. w tys. } \\
\text { PLN }\end{array}$} & \multicolumn{2}{|c|}{$\%$} \\
\hline & & & & KDPW & ogółem & & \begin{tabular}{|c|} 
poza \\
KDPW
\end{tabular} & ogółem \\
\hline Inni & 124889203 & 61,3 & 52199227 & 48,1 & 41,8 & 72689976 & 76,6 & 58,2 \\
\hline Banki & 53641778 & 26,4 & 51608753 & 47,5 & 96,2 & 2033025 & 2,1 & 3,8 \\
\hline JST & 25037685 & 12,3 & 4806200 & 4,4 & 19,2 & 20231485 & 21,3 & 80,8 \\
\hline SUMA & 203568667 & 100,0 & 108614180 & 100,0 & 53,4 & 94954486 & 100,0 & 46,6 \\
\hline
\end{tabular}

Źródło: opracowanie własne na podstawie RZE, dostęp 4.06.2020.

Tabela 2 zawiera statystyki dotyczące liczby serii obligacji w podziale na typ emitenta i miejsce rejestracji. Łączna liczba serii wszystkich niezapadłych obligacji na dzień 30 kwietnia 2020 r. wynosiła 23923 sztuki, z czego aż 92,9\% zarejestrowano poza KDPW. Najwięcej serii obligacji ogółem wyemitowały samorządy $^{18}(73,8 \%)$ - średnia wartość serii to tylko 1,4 mln PLN. W przypadku

${ }^{16}$ Przypomnijmy, że są to obligacje zapisane w ewidencjach firm inwestycyjnych lub banków albo mające formę dokumentu.

${ }^{17}$ Emitentami są tutaj również fundusze inwestycyjne niebędące przedsiębiorstwami.

${ }^{18} \mathrm{~W}$ dotychczasowej praktyce samorządy dzieliły konieczny do pozyskania dług na kilka serii zapadających kolejno rok po roku. Dodatkowo mogły też emitować po kilka serii w ciągu roku, 
emitentów innych niż banki i JST ${ }^{19}$ (głównie przedsiębiorstw) jest to 20,5 mln PLN, a banków aż 255,4 mln PLN. Serie zarejestrowane w KDPW (ok. 64 mln PLN) są istotnie wyższe od tych zarejestrowanych poza KDPW (ok 4,3 mln PLN) ${ }^{20}$. Zdecydowaną większość serii obligacji emitentów innych niż JST i banki $(88,3 \%)$ oraz samorządów $(95,2 \%)$ zarejestrowano poza KDPW.

Tabela 2. Emitenci obligacji wg typu podmiotu oraz miejsca rejestracji - ujęcie ilościowe na dzień 30.04.2020 (obligacje zapadające po 30.04.2020)

\begin{tabular}{|c|c|c|c|c|c|c|c|c|c|c|c|}
\hline \multicolumn{4}{|c|}{ Ogółem } & \multicolumn{4}{|c|}{ w tym w KDPW } & \multicolumn{4}{|c|}{ w tym poza KDPW } \\
\hline \multirow{2}{*}{$\begin{array}{l}\text { Typ } \\
\text { emi- } \\
\text { tenta }\end{array}$} & \multirow{2}{*}{$\begin{array}{c}\text { Liczba } \\
\text { serii }\end{array}$} & \multirow[b]{2}{*}{$\%$} & \multirow{2}{*}{\begin{tabular}{|c|} 
Średnia \\
wartość \\
serii w \\
tys. PLN
\end{tabular}} & \multirow{2}{*}{$\begin{array}{c}\text { Liczba } \\
\text { serii }\end{array}$} & \multicolumn{2}{|c|}{$\%$} & \multirow{2}{*}{\begin{tabular}{|c|} 
Średnia \\
wartość \\
serii w \\
tys. PLN
\end{tabular}} & \multirow{2}{*}{$\begin{array}{l}\text { Liczba } \\
\text { serii }\end{array}$} & \multicolumn{2}{|c|}{$\%$} & \multirow{2}{*}{$\begin{array}{c}\text { Średnia } \\
\text { wartość } \\
\text { serii w } \\
\text { tys. PLN }\end{array}$} \\
\hline & & & & & KDPW & ogółem & & & $\begin{array}{c}\text { poza } \\
\text { KDPW }\end{array}$ & ogółem & \\
\hline Inni & 6086 & 25,4 & 20521 & 715 & 42,1 & 11,7 & 73006 & 5371 & 24,2 & 88,3 & 13534 \\
\hline Banki & 210 & 0,9 & 255437 & 131 & 7,7 & 62,4 & 393960 & 79 & 0,4 & 37,6 & 25734 \\
\hline JST & 17627 & 73,7 & 1420 & 852 & 50,2 & 4,8 & 5641 & 16775 & 75,5 & 95,2 & 1206 \\
\hline SUMA & 23923 & 100,0 & 8509 & 1698 & 100,0 & 7,1 & 63966 & 22225 & 100,0 & 92,9 & 4272 \\
\hline
\end{tabular}

Źródło: opracowanie własne na podstawie RZE, dostęp 4.06.2020.

Tabela 3. Porównanie źródeł informacji o rynku obligacji nieskarbowych na dzień 30.04.2020 w tys. PLN (obligacje zapadające po 30.04.2020)

\begin{tabular}{|l|c|c|c|}
\hline \multicolumn{1}{|c|}{$\begin{array}{c}\text { Źródło i data } \\
\text { danych }\end{array}$} & $\begin{array}{c}\text { Rejestr Zobowiązań } \\
\text { Emitentów }\end{array}$ & $\begin{array}{c}\text { Fitch } \\
\text { Rating\&Rynek }\end{array}$ & NBP \\
\hline \multicolumn{1}{|c|}{ Typ emitenta } & 30.04 .2020 & 30.04 .2020 & 30.04 .2020 \\
\hline Różni (papiery krótkoterminowe) & $\mathrm{n} / \mathrm{d}$ & 12798900 & $\mathrm{n} / \mathrm{d}$ \\
\hline Inne (gł. przedsiębiorstwa) & 124889203 & 70907180 & 85722000 \\
\hline $\begin{array}{l}\text { Banki z BGK } \\
\text { (bez listów zastawnych) }\end{array}$ & 53641778 & 63857850 & 21580600 \\
\hline Samorządy (JST) & 25037685 & 24484590 & 21919000 \\
\hline SUMA w tys. PLN & 203568667 & 172048520 & 129221600 \\
\hline
\end{tabular}

Źródło: opracowanie własne na podstawie RZE, dostęp 4.06.2020; Fitch Polska 2020; NBP 2020.

w zależności od bieżącego zapotrzebowania. Obecnie, m.in. z uwagi na koszty agenta emisji, KDPW oraz obsługi płatności odsetek przez agenta płatniczego, praktyka ta ewoluuje w kierunku łączenia mniejszych wartościowo serii w większe, ale za to amortyzowane.

${ }^{19}$ Jednostki samorządu terytorialnego.

${ }^{20}$ Konieczność pozyskania większego kapitału przez emitenta naturalnie wymusza rejestrację w centralnym rejestrze dla ułatwienia obrotu i zainteresowania potencjalnych inwestorów instytucjonalnych. Praktyką rynkową jest także „doemitowywanie” (tzw. tap) kolejnych obligacji o tych samych warunkach emisji, które mogą być zapisane w KDPW pod tym samym kodem ISIN jako ta sama seria obligacji (będą podlegać asymilacji), dzięki czemu takie obligacje mogą mieć potencjalnie wyższą płynność, niż gdyby były zarejestrowane jako dwie osobne serie. 
Rejestr Zobowiązań Emitentów powinien wg założeń ustawodawcy pokazywać kompletny obraz polskiego rynku obligacji nieskarbowych, dlatego warto porównać go z innymi publicznie dostępnymi statystykami Fitch Polska [Fitch Polska 2020] oraz NBP [NBP 2020]. Efektem tego porównania jest tabela 3.

Najbardziej zbliżone do siebie są wartości obligacji komunalnych (od 22 do 25 mld PLN) ${ }^{21}$. W przypadku papierów bankowych Fitch podaje wyższe wartości niż RZE, ale wynika to głównie z uwzględniania bankowych papierów wartościowych, których w RZE przeważnie nie ma. W przypadku innych emitentów (gł. przedsiębiorstw) RZE podaje znacznie wyższe wartości. Aby zrozumieć te istotne różnice należy zrozumieć założenia metodologiczne raportów Fitch i NBP. Statystyki Fitch ${ }^{22}$ powstają na bazie danych przesyłanych przez największe instytucje finansowe plasujące papiery dłużne (dilerzy), dlatego też nie obejmują m.in. danych o obligacjach materialnych wyemitowanych bez udziału dilera. Z kolei raporty NBP powstają na bazie sprawozdań miesięcznych otrzymanych jedynie od panelu banków, dlatego też należy je traktować z pewnym dystansem, choć w przekroju czasowym mogą wskazywać na pewne tendencje zmian w portfelach obligacji poszczególnych grup inwestorów ${ }^{23}$.

Skoncentrujemy się teraz wyłącznie na danych z RZE. Biorąc pod uwagę wartość nominalną wyemitowanych obligacji, dwudziestu największych emitentów to ponad połowa $(52,4 \%)$ całego rynku obligacji nieskarbowych w Polsce (tabela 4). Największymi z nich są BGK oraz PFR SA, a przewaga ta wzrosła dzięki emisjom obligacji COVID ${ }^{24}$. Branżowo w poniższym zestawieniu zdecydowanie dominują instytucje finansowe oraz spółki energetyczne, większość papierów $(69,2 \%)$ zarejestrowano w KDPW, a przeszło 90\% łącznej wartości nominalnej wyemitowały spółki pod kontrolą Skarbu Państwa.

${ }^{21}$ Fitch do emitentów obligacji komunalnych zalicza też spółki komunalne (np. MPWIK).

${ }^{22}$ Oto założenia metodologiczne raportu Rating\&Rynek, które częściowo wyjaśniają różnice w stosunku do danych RZE i NBP : 1) podział na obligacje przedsiębiorstw, banków i JST dotyczy papierów o zapadalności powyżej 365 dni, a pozostałe papiery ujęto razem jako krótkoterminowe - ich łączna wartość na 30.04.2020 r. wyniosła 12.798,90 mln PLN; 2) wśród banków ujęto również papiery dłużne niebędące obligacjami (np. bankowe papiery wartościowe); 3) raport zawiera nieliczne obligacje funduszy inwestycyjnych, których w RZE jest więcej; 4) źródłem raportu są dane przekazywane dobrowolnie przez instytucje finansowe, w których zdarzają się błędy polegające np. na nieprawidłowej wartości lub w ogóle braku danej serii obligacji w wykazie; 5) raporty Rating\&Rynek zawierają również informacje o wielkości długu uplasowanego przez poszczególnych dilerów, dlatego są podstawowym źródłem informacji o udziałach dilerów w rynku obligacji.

${ }^{23}$ Chodzi np. o instytucje monetarne, fundusze inwestycyjne czy instytucje ubezpieczeniowe.

${ }^{24}$ Jako obligacje COVID rozumiane są specjalne obligacje emitowane po 31 marca $2020 \mathrm{r}$. przez Bank Gospodarstwa Krajowego oraz Polski Fundusz Rozwoju SA na rzecz Funduszu Przeciwdziałania COVID-19 w oparciu m.in. o ustawę z dnia 27 października 1994 r. o autostradach płatnych oraz o Krajowym Funduszu Drogowym (Dz.U. 2020, poz. 72, 278, 1087 z późn. zm.). Na dzień 4.06.2020 obligacje PFR SA i BGK miały łączną wartość nominalną ponad 92,3 mld PLN, podnosząc wartość całego rynku obligacji nieskarbowych do 259,4 mld PLN. W kolejnych analizach zasadne będzie wyłączenie ze statystyk wszystkich serii obligacji objętych gwarancją Skarbu Państwa, ponieważ de facto należy je traktować jak obligacje skarbowe. 
Tabela 4. Emitenci z najwyższą wartością nominalną wyemitowanych obligacji na dzień 30.04.2020 (obligacje zapadające po 30.04.2020)

\begin{tabular}{|c|c|c|c|c|c|}
\hline \multirow[b]{2}{*}{ Lp. } & \multirow[b]{2}{*}{ Emitent } & \multirow{2}{*}{$\begin{array}{c}\text { Liczba } \\
\text { serii }\end{array}$} & \multicolumn{3}{|c|}{ Wartość nominalna obligacji w tys. PLN } \\
\hline & & & ogółem & w tym KDPW & $\begin{array}{c}\text { w tym } \\
\text { poza KDPW }\end{array}$ \\
\hline 1 & Bank Gospodarstwa Krajowego & 9 & 26570000 & 26570000 & 0 \\
\hline 2 & Polski Fundusz Rozwoju SA & 1 & 16325000 & 16325000 & 0 \\
\hline 3 & PGE Górnictwo i Energetyka Konwencjonalna SA & 17 & 10930000 & 0 & 10930000 \\
\hline 4 & ENEA SA & 20 & 7718000 & 2000000 & 5718000 \\
\hline 5 & Powszechna Kasa Oszczędności Bank Polski SA & 3 & 6075000 & 6075000 & 0 \\
\hline 6 & PKP Polskie Linie Kolejowe SA & 4 & 3877145 & 0 & 3877145 \\
\hline 7 & Santander Bank Polska SA & 3 & 3790000 & 3790000 & 0 \\
\hline 8 & TAURON Polska Energia SA & 23 & 3492300 & 1605000 & 1887300 \\
\hline 9 & PKO Bank Hipoteczny SA & 11 & 3036000 & 3036000 & 0 \\
\hline 10 & Bank Polska Kasa Opieki SA & 5 & 2750000 & 2750000 & 0 \\
\hline 11 & CAN-PACK SA & 9 & 2658000 & 0 & 2658000 \\
\hline 12 & ENEA Wytwarzanie Sp. z o.o. & 10 & 2650000 & 0 & 2650000 \\
\hline 13 & Polska Grupa Górnicza SA & 15 & 2619197 & 0 & 2619197 \\
\hline 14 & ENEA OPERATOR Sp. z o.o. & 10 & 2486732 & 0 & 2486732 \\
\hline 15 & Powszechny Zakład Ubezpieczeń SA & 1 & 2250000 & 2250000 & 0 \\
\hline 16 & Alior Bank SA & 11 & 2030200 & 1985200 & 45000 \\
\hline 17 & KGHM Polska Miedź SA & 2 & 2000000 & 2000000 & 0 \\
\hline 18 & Cyfrowy Polsat SA & 2 & 2000000 & 2000000 & 0 \\
\hline 19 & Bank Millennium SA & 3 & 1780000 & 1780000 & 0 \\
\hline \multirow[t]{2}{*}{20} & „PEKAO LEASING” Sp. z o.o. & 13 & 1690000 & 1690000 & 0 \\
\hline & SUMA & 172 & 106727574 & 73856200 & 32871374 \\
\hline
\end{tabular}

Źródło: opracowanie własne na podstawie RZE, dostęp 4.06.2020.

Tabela 5 ukazuje największych emitentów obligacji pod kątem niespełnionych świadczeń ${ }^{25}$. Na pierwszym miejscu jest Getback SA, który wyemitował aż 307 serii obligacji o średniej łącznej wartości nominalnej zaledwie 7,3 mln PLN ${ }^{26}$. Łączna wartość niespełnionych świadczeń z obligacji dla 20 największych

${ }^{25}$ RZE pokazuje trzy kategorie zobowiązań dla każdej serii obligacji - wartość nominalna emisji, wymagane świadczenia (suma płatności, które powinny już być dokonane) oraz niewykonane świadczenia.

${ }^{26}$ Stosunkowo nieduża średnia wartość serii wynika $\mathrm{z}$ tego, że papiery Getbacku oferowano głównie osobom fizycznym w ramach tzw. „pełzających” ofert niepublicznych (tj. jedną serię kierowano do maks. 149 osób). 
podmiotów wynosi ponad 3,6 mld PLN, czyli niecałe 2,9\% łącznej wartości nominalnej obligacji emitentów innych niż banki i samorządy (gł. przedsiębiorstwa). Wartość wszystkich niespełnionych świadczeń z obligacji wg RZE wynosi prawie 4,8 mld PLN, tj. 2,3\% wartości nominalnej wszystkich obligacji.

Tabela 5. Emitenci z najwyższą wartością wymaganych i niespełnionych świadczeń z obligacji na dzień 30.04.2020

\begin{tabular}{|c|c|c|c|c|c|c|}
\hline \multirow[b]{2}{*}{ Lp. } & \multirow[b]{2}{*}{ Emitent } & \multirow{2}{*}{$\begin{array}{c}\text { Liczba } \\
\text { serii }\end{array}$} & \multirow{2}{*}{$\begin{array}{c}\text { Wartość } \\
\text { niespełnionych } \\
\text { świadczeń } \\
\text { z obligacji } \\
\text { w tys. PLN } \\
\end{array}$} & \multicolumn{3}{|c|}{$\begin{array}{c}\text { Wartość nominalna obligacji } \\
\text { w tys. PLN }{ }^{18}\end{array}$} \\
\hline & & & & ogółem & $\begin{array}{l}\text { w tym } \\
\text { KDPW }\end{array}$ & $\begin{array}{c}\text { w tym } \\
\text { poza } \\
\text { KDPW }\end{array}$ \\
\hline 1 & Getback SA w restrukturyzacji & 307 & 2640706 & 2240912 & 545451 & 1695461 \\
\hline 2 & Idea Money SA & 12 & 242450 & 505270 & 0 & 505270 \\
\hline 3 & Gant Development SA & 9 & 127307 & 143932 & 114827 & 29105 \\
\hline 4 & PBG SA w restrukturyzacji & 11 & 115643 & 1172256 & 338356 & 833900 \\
\hline 5 & Action SA w restrukturyzacji & 1 & 101608 & 100000 & 100000 & 0 \\
\hline 6 & Gwarna Wrocław Sp. z o.o. & 4 & 87450 & 20449 & 0 & 20449 \\
\hline 7 & PCZ SA w upadłości likwidacyjnej & 7 & 73156 & 71690 & 71690 & 0 \\
\hline 8 & Progres Investment SA w upadłości & 2 & 54871 & 50000 & 30000 & 20000 \\
\hline 9 & Debt Factory Sp. z o.o. & 31 & 53576 & 34776 & 0 & 34776 \\
\hline 10 & Zakłady Mięsne Henryk Kania SA & 3 & 52651 & 150900 & 150900 & 0 \\
\hline 11 & Atlantic Trust SA & 1 & 49152 & 35000 & 0 & 35000 \\
\hline 12 & Recykling I Energia SA & 1 & 47330 & 36400 & 0 & 36400 \\
\hline 13 & Upturn SA & 1 & 40000 & 40000 & 40000 & 0 \\
\hline 14 & Trust SA & 3 & 39747 & 35683 & 35683 & 0 \\
\hline 15 & Rubin Energy Sp. z o.o. & 2 & 38707 & 38000 & 0 & 38000 \\
\hline 16 & Milmex Systemy Komputerowe Sp. z o.o. & 5 & 34911 & 33205 & 28135 & 5070 \\
\hline 17 & Lmb Capital SA & 4 & 33863 & 33000 & 0 & 33000 \\
\hline 18 & Polimex-Mostostal SA & 5 & 33302 & 172650 & 0 & 172650 \\
\hline 19 & EZO SA & 6 & 32541 & 25500 & 0 & 25500 \\
\hline \multirow[t]{2}{*}{20} & Kerdos Group SA w restrukturyzacji & 6 & 31154 & 35206 & 31154 & 4052 \\
\hline & SUMA & 421 & 3930126 & 4974829 & 1486196 & 3488633 \\
\hline
\end{tabular}

Źródło: opracowanie własne na podstawie RZE, dostęp 4.06.2020.

Na wykresie 1 przedstawiono rozdrobnienie emitentów obligacji. Emitenci, którzy wyemitowali obligacje o łącznej wartości nominalnej min. $100 \mathrm{mln}$ PLN, stanowią zaledwie 8,8\% wszystkich emitentów. Oznacza to, że większość 
emitentów (56,7\%) stanowią spółki, które wyemitowały nie więcej niż $15 \mathrm{mln}$ PLN obligacji, co świadczy o dużym rozdrobnieniu rynku. Warto podkreślić, że najmniejsi emitenci obligacji ( $\mathrm{tj}$. emitujący mniej niż 25 mln PLN) znajdują się poza potencjalnym kręgiem zainteresowania inwestorów instytucjonalnych ${ }^{27}$.
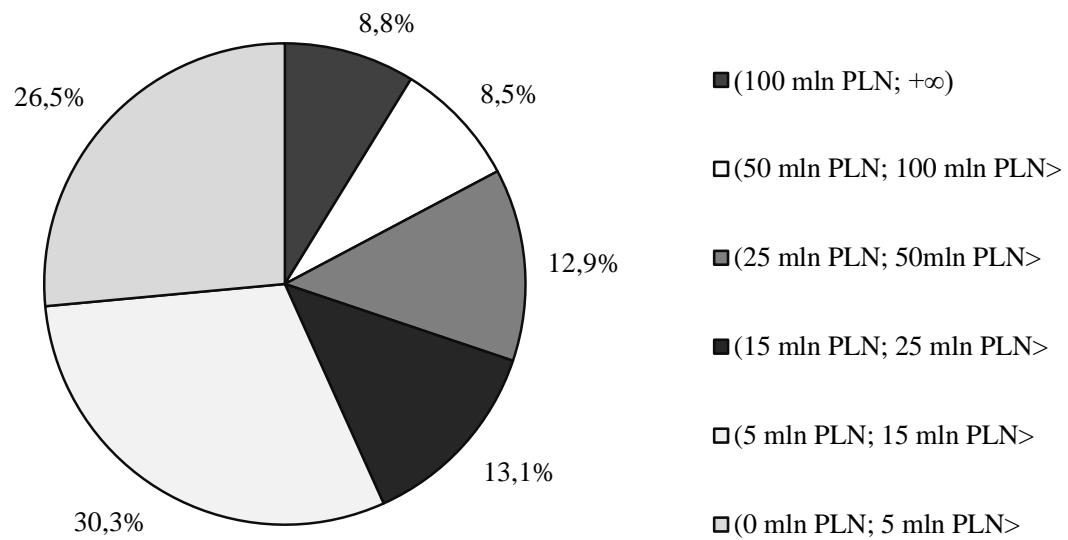

Wykres 1. Emitenci obligacji (razem 2221 podmiotów) wg udziału w łącznej wartości nominalnej wyemitowanych obligacji na dzień 30.04.2020 (obligacje zapadające po 30.04.2020)

Źródło: opracowanie własne na podstawie RZE, dostęp 4.06.2020.

Z RZE wynika także, że wśród obligacji wyemitowanych do końca 2019 r. i zapadających po 30 kwietnia 2020 r., tylko ok. 11,5\% serii obligacji (w ujęciu wartościowym ok. 20\%) posiada stałe oprocentowanie ${ }^{28}$. Zdecydowana większość obligacji nieskarbowych na polskim rynku (z wyłączeniem stałokuponowych obligacji COVID emitowanych przez BGK i PFR SA) posiada zmienne oprocentowanie oparte o odpowiedni indeks WIBOR. W rejestrze RZE nie znajdziemy niestety m.in. informacji o wysokości zmiennej marży, kowenantach, zabezpieczeniach, ani też o wartości pozostającego aktualnie do spłaty kapitału, jeżeli obligacje są amortyzowane ${ }^{29}$. Wysokość kuponu można policzyć, dzieląc wartość ostatnio wypłaconych odsetek przez nominał serii z uwzględnieniem

${ }^{27}$ Po pierwsze, instytucje finansowe muszą przestrzegać limitów zaangażowania $\mathrm{w}$ danym podmiocie (np. max 20\% emisji). Po drugie, zbyt mała kwota inwestycji jest nieefektywna z punktu widzenia operacyjnego, m.in. z uwagi na konieczność przeprowadzenia analiz, wyliczeń ratingu, akceptacji komitetów inwestycyjnych itp.

${ }^{28} \mathrm{~W}$ arkuszu XML za zmienny kupon uznano wartość oprocentowania równą 0 .

${ }^{29}$ Szczegółowe warunki emisji obligacji notowanych na Catalyst są dostępne w formie not informacyjnych na stronie GPW Catalyst [www1, dostęp 4.06.2020]. 
częstotliwości wypłaty (głównie kwartalnej lub półrocznej), a następnie od wartości kuponu odjąć odpowiednią wartość indeksu WIBOR ${ }^{30}$.

Mimo pewnych ograniczeń i dostrzeżonych błędów, dzięki RZE można wreszcie poznać pełniejszy i przede wszystkim publicznie dostępny obraz polskiego rynku obligacji nieskarbowych ${ }^{31}$. Wybrane informacje o papierach, które wcześniej były „rozproszone” w wielu różnych rejestrach, zebrano wreszcie w jednym miejscu. Na pierwszy rzut oka wydaje się, że surowa informacja o łącznym zadłużeniu danego emitenta (wynikającym z obligacji) niewiele mówi o jego sytuacji finansowej, jeśli nie odniesie się jej np. do sumy bilansowej. Informacja ta $\mathrm{z}$ pewnością jest przydatna dla zarządzających funduszami inwestycyjnymi, którzy nabywając papiery dłużne muszą przestrzegać limitów zaangażowania $\mathrm{w}$ danym emitencie ${ }^{32}$.

Spójny rejestr obligacji ma także niebagatelne znaczenie z punktu widzenia nadzoru nad rynkiem, gdyż pozwala Komisji Nadzoru Finansowego na poznanie skali zadłużenia oraz przeprowadzenie „punktowej” kontroli, zarówno u emitenta, jak i u agenta emisji, który dany papier zarejestrował. Warto podkreślić, że wprowadzenie instytucji agenta emisji teoretycznie poprawiło bezpieczeństwo rynku i „sprofesjonalizowało" emisje obligacji m.in. dzięki weryfikacji ustawowych wymogów w zakresie trybu oferowania długu i informacji udostępnianych przez emitenta (np. czy obligacje powinny być oferowane w oparciu o prospekt emisyjny zatwierdzany przez KNF).

Oczywiście pamiętajmy, że żaden, nawet najdokładniejszy rejestr, nie stanowi skutecznej bariery dla przestępczości finansowej i missellingu. Łatwo zauważyć, że w celu ukrycia łącznej wartości zadłużenia z tytułu obligacji, spółka może emitować dług pośrednio poprzez spółki córki mające zupełnie inne nazwy. Ponadto należy pamiętać o ryzyku nieprzekazania lub przekazania błędnych/niepełnych danych przez agenta emisji lub agenta płatniczego lub przez samego emitenta do RZE, mimo iż grozi za to kara grzywny do 2 mln PLN ${ }^{33}$.

${ }^{30}$ O rentowności papieru prócz kuponu decyduje też jego cena. Przykładowo, obligacje mogą być emitowane $\mathrm{z}$ niskim kuponem, ale $\mathrm{z}$ dużym dyskontem do wartości nominalnej. W ten sposób realny koszt dla emitenta obligacji jest „przesuwany” w kierunku zapadalności.

${ }^{31}$ Innym cennym źródłem informacji o polskim rynku papierów dłużnych są miesięczne raporty „Rating\&Rynek”, które powstają na bazie informacji przekazywanej agencji Fitch Ratings przez instytucje oferujące obligacje.

${ }^{32}$ Przykładowo, zgodnie z art. 96 ust. 1 ustawy z dnia 27 maja 2004 r. o funduszach inwestycyjnych i zarządzaniu alternatywnymi funduszami inwestycyjnymi [Dz.U. 2020, poz. 95, 695 z późn. zm.], fundusz inwestycyjny otwarty nie może lokować więcej niż 5\% wartości swoich aktywów w papiery wartościowe wyemitowane przez jeden podmiot.

${ }^{33}$ Art. 178 c ustawy o obrocie [Dz.U. 2020, poz. 89 z późn. zm.]. 


\section{KLUCZOWE CECHY RYNKU OBLIGACJI KOMUNALNYCH}

Wśród obligacji nieskarbowych na szczególną uwagę zasługują obligacje komunalne. Dla samorządów są one atrakcyjnym substytutem kredytu bankowego. Emisja obligacji nie wymaga przeprowadzenia sformalizowanego przetargu wedle przepisów Ustawy o finansach publicznych ${ }^{34}$. Ponadto każdej serii obligacji, różniących się od siebie nie tylko wartością nominalną, ale także dniem emisji i wykupu, można przypisać różną marżę, obniżając w ten sposób średni koszt finansowania mierzony wewnętrzną stopą zwrotu (IRR) ${ }^{35}$.

Dla inwestorów indywidualnych obligacje komunalne są praktycznie niedostępne, ponieważ większość z nich tuż po emisji trafia na stałe do portfeli kredytowych ${ }^{36}$ banków $^{37}$, dla których są atrakcyjnym aktywem pod kątem ryzyka. Samorządy nie mogą formalnie upaść i reprezentują nieco wyższy poziom ryzyka kredytowego niż obligacje skarbowe, obciążając kapitały banków tylko w $20 \%{ }^{38}$. $\mathrm{Z}$ tego powodu banki rzadko sprzedają obligacje komunalne, dlatego zmienność ich cen jest niższa niż cen obligacji skarbowych.

Większość rzadkich transakcji obligacjami komunalnymi odbywa się na pozagiełdowym rynku OTC (tak jak w przypadku innych obligacji nieskarbowych ${ }^{39}$ ), dlatego też zupełnie traci na znaczeniu najważniejsza cecha obligacji komunalnych jako papieru wartościowego, czyli ich zbywalność. Wprawdzie kilkanaście serii komunalnych jest notowanych na Catalyst, jednak obrót nimi jest bardzo niewielki. Celem wprowadzenia tych papierów na rynek regulowany było w zasadzie jedynie obniżenie kosztów płynności przez banki będące ich obligatariuszami ${ }^{40}$. $\mathrm{Z}$ tego powodu stworzenie platformy Catalyst niewiele przyczyniło się do rozwoju samorządowego rynku papierów wartościowych [Hajdys 2019: 16-32]. W praktyce jedyną szansą dla inwestora indywidualnego na zakup długu samorządowego jest zakup

${ }^{34}$ Wynika to z art. 11 ust. 1 pkt 7 Ustawy z dnia 29 stycznia 2004 r. - Prawo zamówień publicznych [Dz.U. 2019, poz. 1843]. Samorządy organizują konkursy na organizację emisji i nabycie obligacji, ale warunki tych konkursów mogą kształtować w dowolny sposób. Przeważnie JST są tu wspierane przez wyspecjalizowane firmy doradcze, a do konkursów zaprasza się banki.

${ }^{35}$ Dla amortyzowanego kredytu stworzenie ,szarpanej”, rosnącej marży jest trudne.

${ }^{36}$ Zgodnie ze standardem IFRS9 portfelami kredytowymi nazywa się portfele hold to collect, w których papiery są zasadniczo trzymane aż do zapadalności; wycena takich portfeli dokonywana jest za pomocą efektywnej stopy procentowej przy stałej wartości nominalnej; zob. www2, dostęp 4.06.2020.

${ }^{37}$ Według NBP w portfelach banków na 30 kwietnia 2020 r. znajdowało się niecałe 89\% obligacji komunalnych - www3, dostęp 4.06.2020.

${ }^{38}$ Chodzi o wartość aktywów ważonych ryzykiem (RWA, risk weighted assets), używaną do obliczania współczynnika wypłacalności Banku zgodnie z Rozporządzeniem CRR 575/2013.

39 Inwestorzy instytucjonalni preferują handel papierami dłużnymi na rynku OTC m.in. z uwagi na niższe koszty transakcyjne oraz możliwość nie wpływania na cenę rynkową.

${ }^{40}$ Obligacje komunalne o wartości nominalnej przekraczającej $10 \mathrm{mln}$ PLN mogą być uznane przez NBP jako zabezpieczenie w transakcjach typu repo, co pozwala bankom obligatariuszom na obniżenie kosztu płynności związanego z posiadaniem tych obligacji. 
jednostek uczestnictwa funduszy inwestycyjnych, który ma silną ekspozycję na sektor samorządowy. Jest to jednak niszowa kategoria aktywów, ponieważ na dzień 14.06.2020 istniał tylko jeden otwarty subfundusz, który statutowo inwestował co najmniej 50\% swoich aktywów netto w obligacje municypalne [Pekao Obligacji Samorządowych]. Sposobami na zwiększenie dostępności obligacji komunalnych dla inwestorów indywidualnych mogłyby być ich aktywne oferowanie na rynku wtórnym przez banki, a także m.in. zwiększenie wielkości ich serii oraz zwiększenie skali animacji (obecnie jest ona dobrowolna).

W przeciwieństwie do papierów skarbowych, od lutego 2016 r. banki muszą płacić od obligacji municypalnych ,"podatek bankowy”" ${ }^{41}$, który de facto (podobnie jak przy kredytach) zwiększa koszty udzielenia kredytu i podnosi marżę odsetkową. W organizowanych przez samorządy konkursach na finansowanie w formie obligacji, duże banki komercyjne przegrywają z małymi bankami spółdzielczymi, reprezentowanymi przez zreszający je Bank Polskiej Spółdzieczości SA, oraz z Bankiem Gospodarstwa Krajowego, które podatku płacić nie muszą ${ }^{42}$. Co więcej, BGK wykorzystuje również swoją uprzywilejowaną „kosztową” pozycję na rynku kredytowym, gdzie aktywnie oferuje finansowanie przedsiębiorstwom komercyjnym.

Wspomniana przewaga BGK może $\mathrm{w}$ dłuższym terminie doprowadzić do spadku zainteresowania banków komercyjnych długoterminowym inwestowaniem w obligacje samorządowe. $Z$ jednej strony może to osłabić konkurencję i doprowadzić do wzrostu marż obligacji komunalnych, ale z drugiej zaś strony może zmusić banki do poszukiwania innych inwestorów na rynku wtórnym, dla których obligacje samorządowe będą aktywem bardziej atrakcyjnym pod kątem rentowności (np. fundusze inwestycyjne).

\section{ZASTRZEŻENIA DOTYCZĄCE DANYCH W REJESTRZE ZOBOWIĄZAŃ EMITENTÓW}

Podczas analizy rejestru zobowiązań emitentów dostrzeżono pewne cechy i błędy, których uwypuklenie jest istotne pod kątem przyszłych badań nad rynkiem obligacji nieskarbowych, jak i usprawnień samego rejestru. Oto one:

- brak informacji o dokładnej formie obligacji ewidencjonowanych poza KDPW, w tym brak możliwości ustalenia wartości obligacji materialnych;

${ }^{41}$ Jest to efektywnie 0,54\% w skali roku [Martysz i Bartlewski 2018: 101-133].

${ }^{42} \mathrm{~W}$ przypadku banków spółdzielczych wynika to z sumy bilansowej niższej niż 4 mld PLN, natomiast podatek w ogóle nie dotyczy BGK. Ponadto, w przeciwieństwie do banków komercyjnych, BGK nie musi również ponosić kosztów wynikających z ustawy z dnia 10 czerwca $2016 \mathrm{r}$. o Bankowym Funduszu Gwarancyjnym, systemie gwarantowania depozytów oraz przymusowej restrukturyzacji [Dz.U. 2020, poz. 842 z późn. zm.]. 
- dla kilku niezapadłych obligacji łączna wartość nominalna serii wynosi 0 PLN, co może nieznacznie zaburzać wyniki badań;

- niektóre wykupione papiery mają wartość nominalną zero, a niektóre nie;

- zaległości z tytułu obligacji mogą wynikać nie tyle z braku faktycznej zapłaty za odsetki czy kapitał, co z błędu emitenta lub agenta płatniczego, który nie zarejestrował w KDPW informacji o wykonanych płatnościach ${ }^{43}$;

- do tabeli 5 należałoby dodać $80 \mathrm{mln}$ PLN niewykupionych obligacji 5 spółek WI Inwestycje Selektywne; wg rejestru wartość, zarówno wykonanych, jak i niespełnionych świadczeń z tych obligacji wynosi 0 PLN;

- w przypadku kilkudziesięciu serii obligacji o tych samych cechach (m.in. wartość nominalna, skrócona nazwa i zapadalność) trudno jednoznacznie ustalić, czy są to błędne dublety czy dodatkowe emisje o tym samym oznaczeniu.

\section{PODSUMOWANIE}

Pokłosiem afery Getback była gruntowna reforma prawa polskiego rynku obligacji nieskarbowych. Dzięki obowiązkowej rejestracji obligacji w KDPW oraz stworzeniu publicznie dostępnego Rejestru Zobowiązań Emitentów [RZE, dostęp 4.06.2020] ułatwiono obrót obligacjami na rynku wtórnym oraz poprawiono przejrzystość rynku. Nowa instytucja agenta emisji poprawiła bezpieczeństwo rynku obligacji m.in. dzięki weryfikacji wymogów prawnych dotyczących emitetna i trybu oferowania obligacji. RZE pozwala nie tylko sprawdzić skalę i terminowość obsługi obligacyjnego zadłużenia emitentów, ale jest również pierwszym publicznie dostępnym narzędziem służącym do kompleksowej analizy polskiego rynku obligacji nieskarbowych.

Rejestr Zobowiązań Emitentów ujawnił wiele cech rynku obligacji, takich jak m.in. duże rozdrobnienie emitentów, niewielkie i liczne serie obligacji samorządowych, dominację emitentów kontrolowanych przez Skarb Państwa, przewagę obligacji o zmiennym oprocentowaniu oraz to, że obligacje zarejestrowane w KDPW to zaledwie połowa rynku obligacji nieskarbowych, choć udział ten będzie długoterminowo zmierzał do $100 \%$ (z uwagi na obowiązek rejestracyjny). RZE pokazał także skalę niedostępnego dla inwestora indywidualnego rynku obligacji komunalnych, którego obecnymi uczestnikami są niemal wyłącznie banki i instytucje finansowe.

${ }^{43}$ Płatności odsetkowe i spłaty kapitału mogą być dokonywane poza KDPW (tj. bezpośrednio na rachunki obligatariuszy), jednak w takim przypadku, zgodnie z par. 80b [Regulaminu KDPW], konieczne jest potwierdzenie w aplikacji internetowej KDPW, że płatność faktycznie nastąpiła. 
$\mathrm{Na}$ zakończenie warto dodać, że otoczenie niskich stóp procentowych ${ }^{44}$ w dłuższym terminie zmusi inwestorów do poszukiwania wyższych marż i będzie sprzyjać rozwojowi obligacji nieskarbowych. Biorąc pod uwagę rosnące koszty finansowania kredytowego banków można przypuszczać, że przedsiębiorstwa o dobrej sytuacji finansowej będą chętniej emitowały obligacje z myślą o rynku Catalyst, o ile zaakceptują dodatkowe obowiązki informacyjne.

\section{BIBLIOGRAFIA}

Fitch Polska, 2020, Rating \&Rynek, 31.03.2020, https://www.fitchratings.com/research/pl/international-public-finance/rating-rynek-03-2020-27-05-2020 [dostęp 4.06.2020].

Getback SA, 2017, Raport biezacy EBI 39/2017 z dnia 7 kwietnia 2017 r., https://www.getbacksa.pl/relacje-inwestorskie/raporty-biezace/raporty-biezace-ebi [dostęp 4.06.2020].

Getback SA, 2018, Raport bieżacy ESPI 60/2018 z dnia 2 maja 2018 r., https://www.getbacksa.pl/relacje-inwestorskie/raporty-biezace/raporty-biezace-espi [dostęp 4.06.2020].

Hajdys D., 2019, Architektura rynku obligacji komunalnych w Polsce w świetle obowiazujacych przepisów prawa, „Finanse Komunalne”, nr 3.

Komisja Nadzoru Finansowego (KNF), 2018, Komunikat KNF w sprawie oferowania obligacji z. 29 maja 2018 r., https://www.knf.gov.pl/knf/pl/komponenty/img/Komunikat_KNF_ws_oferowania_obligacji_61922.pdf [dostęp 4.06.2020].

Komisja Nadzoru Finansowego (KNF), 2019, Zaktualizowane stanowisko UKNF (...) z dnia 12 sierpnia 2019 r., https://www.knf.gov.pl/knf/pl/komponenty/img/Komunikat_dot_rozporzadzenia_prospektowego_12-08-2019_66779.pdf [dostęp 4.06.2020].

Krajowy Depozyt Papierów Wartościowych (KDPW), Regulamin KDPW, http://www.kdpw.pl/pl/ Regulacje/Strony/regulacje.aspx [dostęp 4.06.2020].

Martysz C., Bartlewski B., 2018, Podatek bankowy - koncepcja europejska i studium przypadków wybranych krajów UE, ,Studia BAS”, nr 1(53), Nowa architektura europejskiego systemu finansowego, Biuro Analiz Sejmowych.

Najwyższa Izba Kontroli (NIK), 2019, Działalność organów i instytucji państwowych oraz podmiotów organizujących rynek finansowy wobec spótki Getback SA, podmiotów oferujacych jej papiery wartościowe oraz ja audytujacych, Informacja o wynikach kontroli, https://www. nik.gov.pl/plik/id,21685,vp,24335.pdf [dostęp 4.06.2020].

Narodowy Bank Polski (NBP), 2020, Nieskarbowe dlużne papiery wartościowe, https://www.nbp.pl /home.aspx?f=/statystyka/dealerska/dealerska.htm [dostęp 4.06.2020].

Pekao Obligacji Samorządowych, statut funduszu, https://pekaotfi.pl/produkty/fundusze-inwestycyjne/pekao-obligacji-samorzadowych [dostęp 4.06.2020].

Rejestr Zobowiązań Emitentów [RZE], https://rze.info/ [dostęp 4.06.2020].

Ustawa z dnia 27 października 1994 r. o autostradach płatnych oraz o Krajowym Funduszu Drogowym, Dz.U. 2020, poz. 72, 278, 1087 z późn. zm.

Ustawa z dnia 29 sierpnia 1997 r. - Prawo bankowe, Dz.U. 2019, poz. 2357 z późn. zm.

Ustawa z dnia 9 września 2000 r. o podatku od czynności cywilnoprawnych, Dz.U. 2020, poz. 815 z późn zm.

Ustawa z dnia 29 stycznia 2004 r. - Prawo zamówień publicznych, Dz.U. 2019, poz. 1843.

${ }^{44}$ Od 29 maja 2020 r. stopa referencyjna NBP wynosi 0,10\%. Do dnia 17 marca 2020 r. stopa referencyjna NBP przez ponad 5 lat wynosiła 1,50\%. 
Ustawa z dnia 27 maja 2004 r. o funduszach inwestycyjnych i zarządzaniu alternatywnymi funduszami inwestycyjnymi, Dz.U. 2020, poz. 95, 695 z późn. zm.

Ustawa z dnia 29 lipca 2005 r. o obrocie instrumentami finansowymi, Dz.U. 2020, poz. 89 z późn. zm.

Ustawa z dnia 15 stycznia 2015 r. o obligacjach, Dz.U. 2015, poz. 238 z późn. zm.

Ustawy z dnia 10 czerwca 2016 r. o Bankowym Funduszu Gwarancyjnym, systemie gwarantowania depozytów oraz przymusowej restrukturyzacji, Dz.U. 2020, poz. 842 z późn. zm.

Ustawa z dnia 9 listopada 2018 r. o zmianie niektórych ustaw w związku ze wzmocnieniem nadzoru nad rynkiem finansowym oraz ochrony inwestorów na tym rynku, Dz.U. 2018, poz. 2243 z późn. zm.

[www1] https://gpwcatalyst.pl/emitenci-obligacji-dokumenty-firmy [dostęp 4.06.2020].

[www2] https://www.grantthornton.global/globalassets/1.-member-firms/global/insights/article-pdfs /ifrs/gti-get-ready-ifrs-9-issue-1-classifying-and-measuring-financial-instruments-upd.pdf [dostęp 4.06.2020].

[www3] https://www.nbp.pl/home.aspx?f=/statystyka/dealerska/dealerska.htm [dostęp 4.06.2020].

\title{
POLISH NON-TREASURY BOND MARKET - NEW BOND REGISTRATION RULES AND ANALYSIS OF THE BOND ISSUERS' REGISTER
}

\begin{abstract}
After the Getback SA scam, a special Bond Issuers' Register (RZE) was created to strengthen market supervision, which makes it easier for investors to search for information on debt securities. Thanks to this register, we can finally learn about the actual size and several important features of the Polish non-Treasury debt securities market. The first objective of the article is to show significant changes in the law concerning the form of registration of bonds and their potential impact on further market development. The second goal is to show the previously unknown scale and main features of the bond market, including in particular municipal bonds.

The first hypothesis is that the obligatory registration of bonds in KDPW together with the publicly available Bond Issuers' Register (RZE) have improved the transparency and security level of the Polish non-treasury bond market and facilitated trading in these securities on the secondary market. The second hypothesis is that the Bond Issuers' Register is the first publicly available tool for a comprehensive analysis of the Polish non-treasury bond market, which revealed, among other things, the high fragmentation of issuers (especially in local government bonds), the dominance of state-controlled issuers, the predominance of floating rate bonds and significant size of the bond market registered outside KDPW.
\end{abstract}

Keywords: non-treasury bonds, municipal bonds, debt securities, bond register, bond issuers' register. 